\title{
Terra Pretas: Charcoal Amendments Influence on Relict Soils and Modern Agriculture
}

\author{
Kristin Ricigliano \\ University of Maryland \\ College Park, MD 20740
}

The purpose of the paper is to investigate the soil organic matter and related properties of Terra Preta soils and to then relate them to modern sustainable agriculture.

This paper is intended for scientists and students interested in the soil fertility of Oxisols. 


\begin{abstract}
Most soils found in the Amazon region are characterized by highly weathered profiles that are incapable of long-term agricultural production. However, small patches of highly fertile relict soil referred to as Terra Pretas, are also found in the Amazon region, and have maintained their integrity for thousands of years. These soils were anthropologically formed, being of preColumbian origin and are unique in their high amounts of charcoal and nutrients compared to the surrounding soils. The charcoal serves to stabilize the organic matter in the soil, increase cation exchange capacity, and increase water retention due to its porous structure and high surface area. Organic wastes, such as bones and manure are thought to be the source of additional nutrients.

To improve the overall productive capacity of the soil in this region, slash and char has been proposed to replace the traditional practice of slash and burn in order to mimic the high amounts of charcoal found in Terra Pretas soils. Instead of burning the vegetation and releasing the carbon into the atmosphere, the vegetation would be charred and the carbon would be sequestered in the soil on a small scale. Furthermore, based on the stability of charcoal and its ability to sequester carbon, some scientists are suggesting we consider pyrolysis (the process that creates charcoal by heating organic material with low amounts of oxygen) and its byproducts as a solution to soil quality issues, global warming, and peak oil. This concept is very controversial and relatively unstudied; further research is needed to truly understand the consequences of sequestering large amounts carbon in the soil and the use of biofuels formed as byproducts of pyrolysis.
\end{abstract}




\section{Introduction}

Most soils in the Amazon region are Oxisols or Ultisols, which are soils characterized by low $\mathrm{pH}$, low CEC, and being dominated by Fe (III) and Al (III) oxides and 1:1 clays from decades of intense weathering. Generally, Oxisols and Ultisols are leached of nutrients essential for microbial and plant life, and as a result these soils are typically infertile and have low potential for agricultural production (Brady and Weil, 2008). However, within this region, there are small patches of unique dark soil that are highly fertile and enriched in organic matter compared to the surrounding infertile soils, as shown in Figure 1 . They are approximately 20 ha in size and are referred to as Terra Pretas or Terra Preta soils, which translates to "dark soil" in Portuguese. Terra Preta soils are pre-Columbian in origin and are important because they were anthropogenically formed either intentionally or as a by-product of occupation and have remained highly productive for centuries (Novotny et al., 2007). Our knowledge of how Terra Preta soils were formed is unknown, but many theories link the processes responsible for the formation of these soils to charcoal, human and animal excrements, as well as human and animal bones (Glaser, 2007). Archeologists speculate that humans added turtle shells, small mammal, fish and human bones to the soil, which added high amounts phosphorus and calcium. Human excrements and manure were probably also added to these soils and provided a source of phosphorus and nitrogen to the soil. Researchers also speculate that the charcoal is present in the soil in such high quantities because it was used for cooking, rituals, and light (Glaser, 2007). Terra Preta soils are considered to be relict soils that could provide insight into transforming infertile Oxisols into fertile soil suitable for sustainable agriculture, while also sequestering significant amounts of carbon. 


\section{Physical and Chemical Properties of Terra Preta soils}

Terra Preta soils have maintained their fertility over thousands of years due to a variety of factors, including the high amount of organic matter found in these soils (Novotny et al., 2009). A major source of carbon in Terra Preta soils is believed to originate from charcoal, which is produced by heating wood or other organic materials with a limited supply of oxygen. This process is referred to as pyrolysis (Brady and Weil, 2008). Some scientists refer to charcoal as a fuel and biochar as a non-fuel that is used to sequester carbon and as a soil amendment, however there is no real difference between charcoal and biochar carbon (Tenenbaum, 2009).

A general morphological description of Terra Preta soils divides the profile into three distinct horizons. The first is a deep, dark and nutrient rich epipedon with a sandy texture and abundance of potsherds. The potsherds serve as further evidence of anthropogenic influence. The second is a transitional horizon with a large quantity of peds and root linings thickly coated in organic mater. The third horizon has a lower percentage of organic matter and as a result the peds are more thinly coated and the soil is lighter in color. It also has a clayey texture (German, 2003). Terra Preta soils are extremely different from the typical profiles found in the Amazon, as shown in Table 1.

Studies have demonstrated that Terra Preta soils typically contain 70 percent more charcoal on average than surrounding soils. Radiocarbon dating of the charcoal in the Terra Preta soils has shown that some of the charcoal dates to 7,000 years old, demonstrating its preColumbian origin (Glaser, 2007). The presence of charcoal in the soil with other highly aromatic humic substances could link the residues of incomplete combustion of organic materials to the stability of the organic matter in these soils (Glaser et al., 2001). 
Terra Preta soils have a carbon content of up to $150 \mathrm{~g} / \mathrm{kg}^{-1}$ of soil, as opposed to $20-30$ $\mathrm{g} / \mathrm{kg}^{-1}$ in surrounding soils (Novotny et al., 2009). The additional carbon content can be attributed to charcoal and its ability to also retain soil organic matter. Charcoal is characterized by carbon with polyaromatic structures. The polyaromatic structures have a surface charge that is variable with $\mathrm{pH}$, but this charge leads to an increase in cation exchange capacity, aggregation, and complex formation (Cunha et al., 2009).

The porous structure of the charcoal also serves as a habitat for microorganisms within the soil. The charcoal and additional nutrients encourages the growth of ecto- and endomycorrhizal fungi and the growth of gram-positive anaerobic bacteria, which produce organic acids (Glaser, 2007). The presence of mycorrhizae fungi promotes nutrient and water retention, and also protects against disease.

The addition of charcoal is beneficial to the soil, but it also has the ability to bind up $\mathrm{N}$ and does not provide many essential nutrients. Therefore, it is important to also add a nutrient source along with charcoal amendments due to charcoal's high C:N ratio (Tenenbaum, 2009). Nutrient inputs are also essential in the tropics due to intense weathering from high amounts of precipitation and high temperatures. The soils found in this region typically have low cation exchange capacity due to the presence of Fe (III) and Al (III) oxides and 1:1 clays that are characterized by a little to no isomorphic substitution and a non-accessible interlayer. Therefore, adding nutrient sources that are slow to degrade, such as organic fertilizers greatly increases microbes and plants ability to obtain these nutrients before they have an opportunity to leach from the system (Lehmann et al., 2003).

The amendment of organic wastes, especially bones and manure to soils can provide the essential nutrients that cannot be fixed through photosynthesis, nitrogen fixation or through the 
weathering of minerals found in Oxisols. Possible anthropogenic nutrient sources include human and animal excrements that are rich in phosphorus and nitrogen, mammal and fish bones high in calcium and phosphorus, ash residues of incomplete combustions that contain calcium, magnesium, potassium, phosphorus and charcoal, as well as terrestrial and aquatic plant biomass (Glaser, 2007).

\section{Implications for Small Scale: Sustainable Land Management}

Terra Preta soils have maintained their agricultural utility for thousands of years, and serve as a relict soil of past land management practices. If it were possible to duplicate the formation of these soils for modern agriculture, it would ease the pressure of the increased demand for food, and consequently, degradation of the land with unsustainable farming practices.

The main farming practice in the tropics is known as slash and burn, and approximately 300-500 million people around the world currently practice it. This farming practice affects onethird of the 1.5 million ha of land suitable for agriculture mainly in developing nations (Steiner $e t$ al., 2007). The traditional agricultural practice of slash and burn consists of burning the forest, cultivating the land for 1 to 3 years, then leaving the land fallow for about 20 years. While it is considered to be a sustainable agricultural practice, recent increases in population and food demand has put increased pressure on farmers to continue using the land beyond its capability to recover. Many nutrients including nitrogen and sulfur, as well as organic matter, are lost in the initial ignition of the forest, and extended cultivation without sufficient time for the land to recover only exacerbates the amount of nutrients and organic matter that are lost from the soil profile (Steiner et al., 2007). Therefore, land degradation, increased pressures for deforestation, and decreases in crop yields are a result of unsustainable practices. 
To address the need for a more sustainable agricultural practice to meet increasing land use requirements, a new agricultural practice, called slash and char, has been suggested that incorporates the benefits of charcoal, while utilizing the native vegetation. Slash and char would produce charcoal from the vegetation through pyrolysis, as opposed to carbon dioxide through burning. Traditional slash and burn releases 38 to 84 percent of the carbon from vegetation into the atmosphere, which increases the anthropogenic greenhouse effect and decreases the amount of carbon sequestered in the soil (Steiner et al., 2007). Charcoal is produced on a large scale in the tropics because it is a cash product, but the pieces that are smaller than $2 \mathrm{~mm}$ cannot be sold. Therefore, the residue wastes from charcoal production can be used as a soil amendment (Glaser, 2007). On a small scale applying charcoal as an alternative to composts and manures as a source of carbon seems to be a promising way to maximize carbon content in soils due to its stability, which is exemplified in Terra Preta soils. Slash and char seems to be an efficient method of tapping into the carbon cycle in order to conserve it in the soil.

\section{Implications for Large Scale Application: Soil Fertility, Peak Oil and Global Warming}

Terra Preta soils inspired a modern debate over the use of charcoal, also known as "biochar" as a large-scale solution to soil quality issues, peak oil, deforestation, global warming and respiratory disease. Charcoal is traditionally produced by burning wood in pits or structures, which releases carbon dioxide; however, scientists believe that a more efficient method of pyrolysis could capture its intermediate byproducts and use them for fuel. This method is referred to as low temperature pyrolysis. With low temperature pyrolysis, biomass is heated to moderate temperatures of about 400 to $500{ }^{\circ} \mathrm{C}$, a temperature range at which the biomass undergoes exothermic reactions that release heat and gases, while producing charcoal (Lehmann, 
2007). These byproducts can be captured to produce an energy source, such as bio-oil, while the charcoal can be added as an amendment to the soil, as shown in Figure 2. This technology would sequester carbon in the soil, while producing energy. Low temperature pyrolysis would not be carbon neutral, but carbon negative due to the net withdrawal of carbon dioxide from the atmosphere (Lehmann, 2007).

However, there are some impediments to applying low temperature pyrolysis on a large scale. First, this field of science is relatively unstudied. There is still much more research that needs to be conducted, including understanding the stability of biochar based on the production process and biomass type, the decomposition rate of newly produced biochar, its influence on the nitrogen cycle, and how to incorporate biochar into the soil to prevent erosion and nutrient loss without degrading the soil structure (Lehmann, 2007).

Biochar produced below $400{ }^{\circ} \mathrm{C}$ has a low $\mathrm{pH}$, low CEC and low surface area, and would not be appropriate to improve soil fertility. However, if biochar is produced above $500{ }^{\circ} \mathrm{C}$ than most of the byproducts are just carbon dioxide. Furthermore, under any production scenario, the CEC of recently produced biochar is low. Only aged biochar shows evidence of a high CEC like the charcoal of Terra Preta soils (Lehmann, 2007). In order to supply to biomass needed to create biochar much of the vegetation would be removed from the land. This is highly extractive and could lead to soil degradation, pollution and increased deforestation. The counterargument to this claim is that biochar would return 50 percent of the original carbon to the soil.

There are also going to be increased carbon dioxide emissions with the production of biomass for pyrolysis, the process of pyrolysis itself, transporting the biochar to various regions, as well as the land application of the biochar. The underlying assumption to this concept is based on the stability of the charcoal found in Terra Preta soils. In theory, the biochar amendments 
would only need to be applied once due to charcoal's stability for hundreds to thousands of years, which would sequester enough carbon to compensate for the production emissions (Lehmann, 2007).

\section{Conclusion}

Terra Preta soils serve as a guide to the sustainable land management our ancestors once practiced. Although researchers are still unsure whether charcoal and nutrient additions to these small patches of land were intentional or as a byproduct of human life, it is well known that Terra Preta soils are unlike the infertile soil that surrounds them. As populations continue to increase, there is a need to find solutions for our food security issues, increased land degradation and the fuel crisis. The tradition of slash and burn cannot withstand the pressures of the increasing population and an alternative sustainable practice must begin on a small scale. Slash and char is not how Terra Preta soils formed, but this land management practice can provide a crucial component of these relict soils: charcoal. The addition of organic wastes, such as manure and bones would compliment the addition of charcoal by providing essential nutrients. Terra Preta soils exemplified the benefits of charcoal and organic fertilizers by being productive for thousands of years, but it is still early to tell whether this is viable to achieve on a large scale. The technology of low temperature pyrolysis to produce biochar is poorly understood and could lead to the displacement of people from their land, increased rates of deforestation and could jeopardize food security from agricultural land being used for carbon sequestration and fuel

production. However, it is a proposed technology that could provide a fuel source and essential soil amendment, while reversing global warming by extracting carbon dioxide from the atmosphere. 


\section{References}

Brady, N.C. and R.R. Weil. 2008. Prospects for Global Soil Quality as Affected by Human Activities. In: The Nature and Properties of Soils. $14^{\text {th }}$ ed. Pearson: Prentice Hall, New Jersey, p. 911.

Cunha, T.J.F., Madari, B.E., Canellas, L.P., Riberiro, L.P., Benites, V., Santos, G., 2009. Soil organic matter and fertility of anthropogenic dark earths (Terra Preta de Indio) in the Brazilian Amazon basin. Revista Brasileira de Ciência do Solo. Vol. 33 no. 1.

German, L.A. 2003. Historical contingencies in the coevolution of environment and livelihood: contributions to the debate of Amazonian Terra Preta soils. Geoderma. 111:301 - 331 .

Glaser, B. 2007. Prehistorically modified soils of central Amazonia: a model for sustainable agriculture in the twenty-first century. Philosophical transactions of the Royal Society. 362:187-196.

Glaser, B., Haumaier, L., Guggenberger, G., Zech, W., 2001. The 'Terra Preta' phenomenon: a model for sustainable agriculture in the humid tropics. Naturwissenchaften. 88:37-41

Lehmann. J. 2007. Bio-energy in the black. Front Ecological Environment. 5(7): 382 - 387.

Lehmann, J., da Silva Jr., J.P., Steiner, C., Nehls, T., Zech, W., Glaser, B., 2003. Nutrient availability and leaching in an archeological Anthrosol and a Ferralsoil of the Central Amazon basin: fertilizer, manure and charcoal amendments. Plant and Soil. 249: 343-357.

Novotny, E.H., Deazevedo. E.R., Bonagamba, T.J., Cunha, T.J.F., Madari, B.E., Benities, V., Hayes M.H.B., 2007. Studies of the Compositions of Humic Acids from Amazonian Dark Earth Soils. Environmental Science and Technology. 41:400-405.

Novotny, E., Hayes, M.H.B, Madari, B.E., Bonagamba, T.J., Deazevedo, E.R., de Souza, A.A., Song, G., Nogueira, C.M, Mangrich, A.S., 2009. Lessons from the Terra Preta de Indios of the Amazon Region for the Utilization of Charcoal for Soil Amendment. J. Braz. Chem. Soc. $20: 1003-1010$

Steiner, C., Keshav C.D., Garcia, M. Forster, B., Zech W., 2008. Charcoal and smoke extract stimulate the soil microbial community in a highly weathered xanthic Ferralsol. Pedo biologia. 51: $359-366$.

Steiner, C., Teixera, W.G., Lehmann, J., Nehls, T., Vaconcelos de Macedo, J.L., Blum W.E.H., Zech, W., 2007. Long term effects of manure, charcoal and mineral fertilization on crop production and fertility on a highly weathered Central Amazonian upland soil. Plant Soil. 291:275-290.

Tenenbaun, D.J. 2009. Carbon Mitigation from the Ground Up. Environmental Health Perspectives. 111(2): $70-73$. 

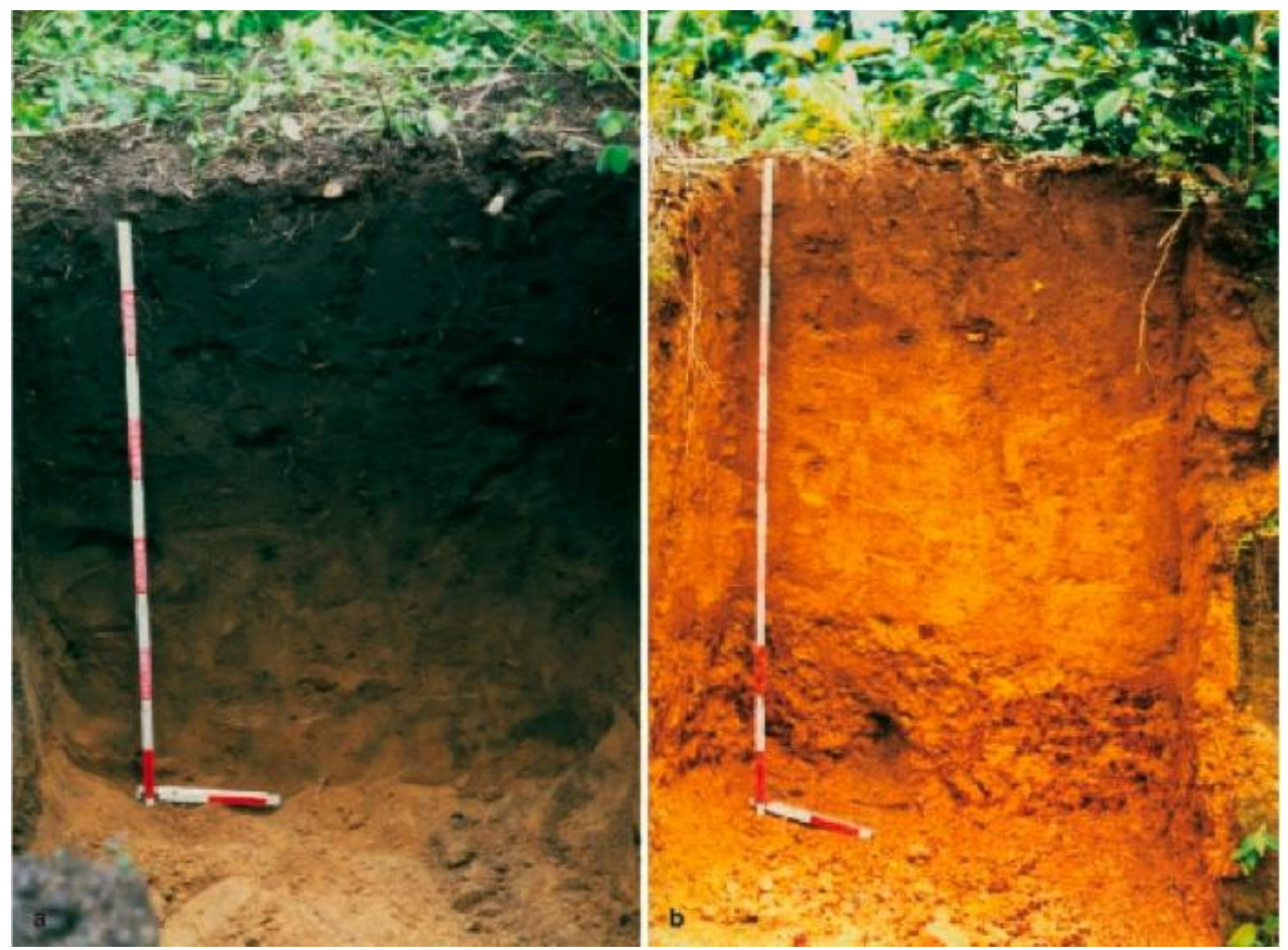

Figure 1. Terra Preta soil (left) compared to a typical Oxisol profile (right). Image from Glaser, B., Haumaier, L., Guggenberger, G., Zech, W., 2001. The 'Terra Preta' phenomenon: a model for sustainable agriculture in the humid tropics. Naturwissenchaften. 88:37-41. 


\begin{tabular}{|c|c|c|c|c|c|c|c|c|c|c|c|c|c|c|c|c|c|}
\hline \multirow[t]{2}{*}{ Soil } & \multirow[t]{2}{*}{ Ho } & \multirow[t]{2}{*}{$\begin{array}{l}\text { Depth }^{1} \\
(\mathrm{~cm})\end{array}$} & \multicolumn{4}{|c|}{$\begin{array}{l}\text { Particle Size } \\
\text { Distribution }\end{array}$} & \multirow[t]{2}{*}{$\begin{array}{l}\mathrm{pH} \\
\left(\mathrm{H}_{2} \mathrm{O}\right)\end{array}$} & \multirow[t]{2}{*}{$\begin{array}{l}\mathrm{P}_{2} \mathrm{O}_{5} \\
(\mathrm{ppm})\end{array}$} & \multicolumn{5}{|c|}{ Exchange Complex (meg/100g) } & \multirow[t]{2}{*}{$\begin{array}{l}\text { Total } \\
\text { C }(\%)\end{array}$} & \multirow[t]{2}{*}{$\begin{array}{l}\text { Total } \\
\mathrm{N}(\%)\end{array}$} & \multirow[t]{2}{*}{$\begin{array}{l}\text { Base } \\
\text { Saturation } \\
(\%)\end{array}$} & \multirow[t]{2}{*}{$\begin{array}{l}\text { CEC } \\
(\mathrm{meq} / \\
100 \mathrm{~g})\end{array}$} \\
\hline & & & $\begin{array}{l}\text { CS } \\
(\%)\end{array}$ & $\begin{array}{c}\text { FS } \\
(\%)\end{array}$ & $\begin{array}{c}\mathrm{S} \\
(\%)\end{array}$ & $\begin{array}{l}\mathrm{CL} \\
(\%)\end{array}$ & & & $\mathrm{Ca}^{2+}$ & $\mathrm{Mg}^{2+}$ & $\mathrm{K}^{+}$ & $\mathrm{Na}^{+}$ & $\mathrm{Al}^{3+}$ & & & & \\
\hline \multirow[t]{4}{*}{ Oxisol } & A & 16 & 28 & 10 & 18 & 43 & 4.3 & 3.6 & 0.11 & 0.10 & 0.04 & 0.02 & 2.34 & 4.5 & 0.1 & 10 & 2.61 \\
\hline & $\begin{array}{l}\text { A } \\
\text { B }\end{array}$ & 45 & 22 & 9 & 20 & 50 & 4.3 & 1.7 & 0.03 & 0.03 & 0.02 & 0.01 & 1.74 & 1.9 & 0.1 & 5 & 1.81 \\
\hline & $\mathrm{B}_{1}$ & 88 & 21 & 13 & 13 & 53 & 4.3 & 2.1 & 0.05 & 0.06 & 0.02 & 0.01 & 1.62 & 1.1 & 0.1 & 8 & 1.76 \\
\hline & $\mathrm{B}_{2}$ & 110 & 8 & 2 & 19 & 71 & 4.5 & 0.7 & 0.01 & 0.01 & 0.01 & 0.01 & 0.93 & $\mathrm{n} / \mathrm{a}$ & $\mathrm{n} / \mathrm{a}$ & 4 & 0.97 \\
\hline \multirow{4}{*}{$\begin{array}{l}\text { Terra } \\
\text { Preta }\end{array}$} & A & 30 & 45 & 14 & 15 & 21 & 5.6 & 68.6 & 5.41 & 0.66 & 0.04 & 0.04 & 0.47 & 3.2 & 0.1 & 93 & 6.62 \\
\hline & $\begin{array}{l}\text { A } \\
\text { B }\end{array}$ & 58 & 39 & 13 & 12 & 37 & 5.2 & 37.4 & 1.63 & 0.22 & 0.01 & 0.01 & 0.72 & 1.5 & 0.1 & 72 & 2.59 \\
\hline & $\mathrm{B}_{1}$ & 96 & 33 & 11 & 11 & 45 & 5.0 & 41.9 & 0.70 & 0.13 & 0.01 & 0.01 & 0.61 & 0.6 & 0.0 & 58 & 1.46 \\
\hline & $\mathrm{B}_{2}$ & 114 & 27 & 8 & 14 & 50 & 4.8 & 39.2 & 0.45 & 0.07 & 0.01 & 0.00 & 0.83 & $\mathrm{n} / \mathrm{a}$ & $\mathrm{n} / \mathrm{a}$ & 39 & 1.36 \\
\hline
\end{tabular}

Table 1. Pedological comparison between Oxisols and Terra Preta soils, Negro and Urubu Rivers.

$\mathrm{CS}=$ Coarse Sand; FS = Fine Sand; $\mathrm{S}=$ Silt; $\mathrm{CL}=$ Clay

${ }^{1}$ Values averaged by horizon from 8 total Oxisols and 8 Terra Preta soils sampled.

Table redrawn from German, L.A. 2003. Historical contingencies in the coevolution of environment and livelihood: contributions to the debate of Amazonian Terra Preta soils. Geoderma. 111:301-331. 


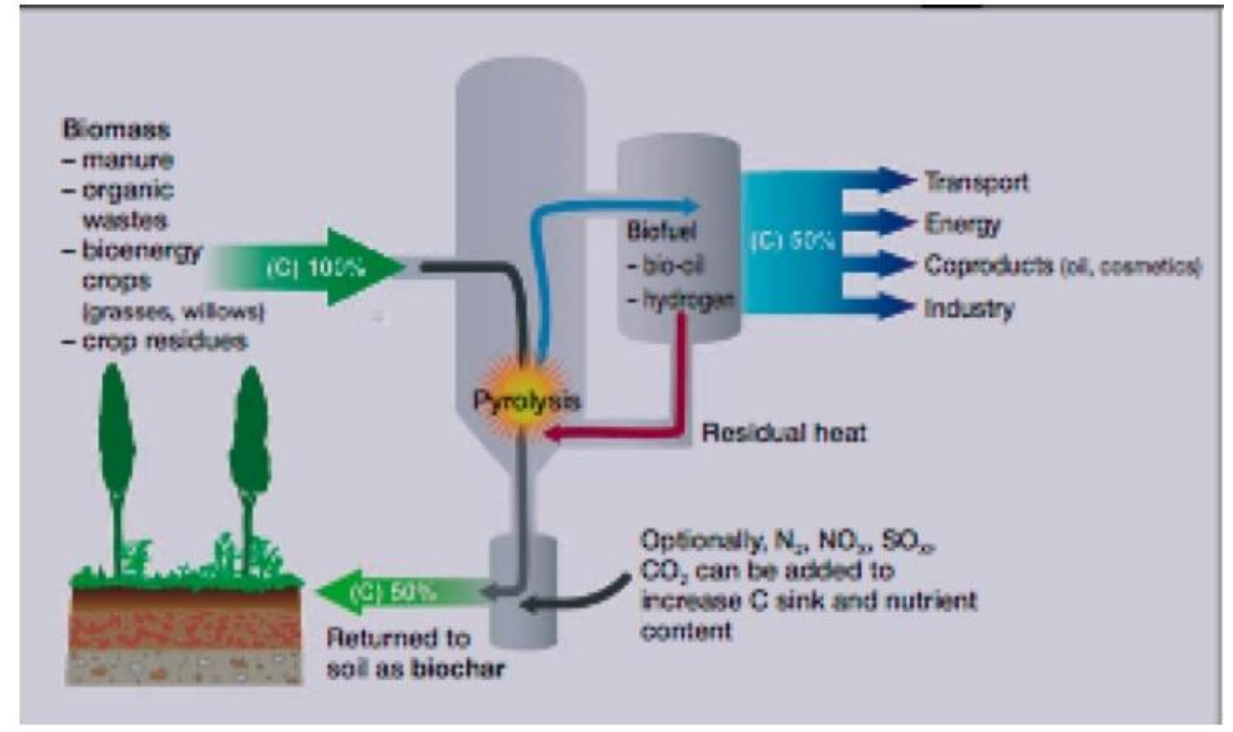

Figure 2. Concept of low temperature pyrolysis to produce charcoal or "biochar." Generally, about 50 percent of biomass becomes charcoal and is added back to the soil (Lehmann, 2007). Image from Lehmann. J. 2007. Bio-energy in the black. Front Ecological Environment. 5(7): 382387. 